\title{
Structure and Functions of Glycosignaling Domain
}

\author{
グリコシグナルドメインの構造と機能 \\ Iwabuchi, Kazuhisa
Institute for Environmental and Gender-specific Medicine, Juntendo University Graduate School of Medicine, \\ Tomioka 2-1-1, Urayasu, Chiba 279-0021, Japan \\ FAX: 81-47-353-3178, E-mail: iwabuchi@ med.juntendo.ac.jp
}

Key Words: glycosphingolipid, microdomain, Src family kinase, glycosignaling domain, adhesion

\begin{abstract}
Glycosphingolipids are membrane components consisting of hydrophobic ceramide and hydrophilic sugar moieties. They cluster with sphingomyelin and cholesterol in cell membrane to form glycosphingolipid-enriched microdomains. Biochemical analyses have demonstrated that glycosphingolipidenriched microdomains contain several kinds of transducer molecules, especially membrane-anchored signal transduction molecules such as Src family kinases. Although it has been speculated that glycosphingolipids are closely associated with cell differentiation, proliferation and functions such as adhesion, there is quite a lot of evidence that glycosphingolipids by themselves directly mediate signal transductions, which lead to cell functions. Glycosignaling domains (GSDs) have been identified as glycosphingolipid-mediated signal transduction units in mouse melanoma B 16 cells, mouse neuroblastoma Neuro2a cells and human neutrophils. In those cells, certain kinds of glycosphingolipids, e.g. LacCer for neutrophils, are highly expressed on cell surfaces, and associated with Src family kinases in GSD. Glycosphingolipids in GSD specifically recognize carbohydrate epitopes of ligands and mediate cell functions such as adhesion and superoxide generation. Unlike other types of microdomains, GSD-mediated cell functions and associated signaling are not reduced or abolished in the presence of either filpin or methyl- $\beta$-cycrodextrin, which are cholesterol-binding reagents known in general to abolish microdomain structures and their functions. The remaining problem to be solved is how glycosphingolipids transmit signal transduction molecules in GSD.
\end{abstract}

\section{A. Introduction}

There are several kinds of leukocytes, which play specialized functions in each cell for host defense. Leukocytes are always produced from anaplastic haematopoietic stem cells. Along with cell differentiation, leukocytes express several kinds of molecules on plasma membranes, which are named as cluster differentiation (CD). The CD molecules expressed by each leukocyte act as more than mere differentiation makers, and most
要 約

スフィンゴ糖脂質は疎水性のセラミドと親水性の糖鎖から なる膜成分である。スフィンゴ糖脂質はスフィンゴミエリンや コレステロールとともに会合して細胞膜上でマイクロドメイン を形成している。また、生化学的な分析から、スフィンゴ糖脂 質に富んだマイクロドメインには様々な細胞内情報伝達分子、 特にSrc family kinase のような細胞膜に結合する情報伝達分子 が含まれていることが明らかとなった。スフィンゴ糖脂質は細 胞分化や増殖、細胞接着などの細胞機能と密接に関係している と推測されているが、グライコスフィンゴ糖脂質自身が、細胞 機能発現をもたらすような情報伝達を直接仲介するという証拠 はほとんど得られていない。グリコシグナルドメイン (GSD) は マウスメラノーマB16 細胞、マウス神経芽細胞 Neuro2a jよ びヒト好中球においてスフィンゴ糖脂質を介した情報伝達ユ ニットとして同定されている。これらの細胞では、たとえば好 中球には LacCer といった特定のスフィンゴ糖脂質が細胞膜上 にたくさん発現されており、Src family kinase と GSD で会合し ている。GSDにおいてスフィンゴ糖脂質はリガンドの糖鎖エピ トープを特異的に認識し、細胞接着や活性酸素産生などの細胞 機能を仲介する。他の種類のマイクロドメインとは異なり、 GSD が仲介する細胞機能とそれに関連する情報伝達は、マイク ロドメインの構造と機能を壞すことが一般には知られている

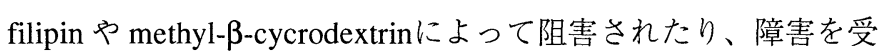
けることはない。今後解決すべき課題は如何にしてスフィンゴ 糖脂質が GSD において細胞内情報伝達分子に情報を伝えてい るかである。

\section{A. はじめに}

白血球には様々な種類の細胞があり、生体防御においてそ れぞれが独自の機能を果たしている。各白血球は常に未分化な 細胞から分化成熟して作り続けられており、この過程で白血球 は cluster of differentiation (CD) と呼ばれる分子を細胞膜表面に 発現する。各白血球は $\mathrm{CD}$ 分子を単なる分化マーカーとして発 現しているわけではなく、多くの CD 分子は各細胞において分 化段階に応じて重要な機能を発揮していると考えられている。 
of them provide important functions along with differentiation phases. However, the functions of those molecules are not well understood. Based on the sugar chain structure, more than 400 species of glycosphingolipids have been identified, although its abundance is low in membrane lipids (1). Glycosphingolipids have attracted considerable interest because lineage-related and differentiation-dependent expressions of these molecules are well documented for leukocytes. Therefore, those molecules have been believed to perform significant functions in leukocytes. Although glycosphingolipids have been used as differentiation markers, the glycosphingolipid-mediated functions in leukocytes have not been well identified.

LacCer appears on plasma membrane of circulating mature neutrophils (2). It is well known that several kinds of pathogenic microorganisms can bind to LacCer (3-5). However, the roles of LacCer in neutrophil functions remain obscure. Recently, it has been demonstrated that glycosphingolipids cluster to form microdomains coupled with transducer molecules on plasma membrane. Actually, we found that LacCer forms glycosignaling domains (GSD) coupled with Src family protein tyrosine kinase (Src-PTK) Lyn and functions as an adhesion molecule. This mini review introduces how glycosignaling domains, which are the glycosphingolipid-mediated signal transduction unit, recognize the ligands and signal into cells.

\section{B. The Molecular Mechanisms of Binding of Glycosphingolipids with Their Ligands}

After the discovery of glycosphingolipids, the physiological functions of glycosphingolipids have been analyzed. Because glycosphingolipids express themselves on cell surface, it has been speculated that glycosphingolipids function as receptors. Although several molecules have been reported as ligands for glycosphingolipids, many of them could not be elucidated. Among those candidates, microorganism-derived molecules such as cholera toxin have been successfully identified as ligands for glycosphingolipids (1). For example, the pentameric B-subunit of the cholera toxin can bind to GM1-ganglioside receptors, leading to toxin entry into mammalian cells (6). Several kinds of pathogenic microorganisms including viruses can directly bind glycosphingolipids $(3,7-10)$. However, pathogenic microbes utilize glycosphingolipids as targets for infecting. There is no clear evidence that glycosphingolipids except for LacCer mediate cell functions through the binding with microorganisms.

Since the specific sugar chains like $\mathrm{Le}^{\mathrm{x}}$ are expressed on cell membrane in the differentiation stage which relates to cell adhesion, the glycosphingolipids having $\mathrm{Le}^{\mathrm{x}}$ may be involved in cell adhesion. The expression pattern of the glycosphingolipids on cell surface changes with the canceration. Thus, the glycosphingolipids, in which the expression level changes with the canceration, may cause metastasis (11). Mammalian cells recognize the expression changing of glycosphingolipids through
しかしながら、それらの分子には未だに機能が明らかではない 分子も少なくない。スフィンゴ糖脂質は細胞膜を構成する糖脂 質であり、細胞膜脂質としての割合は少ないが、糖鎖構造の違 いによって 400 種類以上がこれまでに同定されている (1)。白 血球は細胞膜表面に分化段階に応じて様々なスフィンゴ糖脂質 を発現しているだけではなく、白血球ごとに発現しているス フィンゴ糖脂質の種類が異なっている。したがって、スフィン ゴ糖脂質が各白血球に打いて重要な機能を果たしていると考え られている。しかしながら、これまでのところスフィンゴ糖脂 質は分化抗原マーカーとして利用されることはあっても自らを 介して各細胞が具体的にどのような機能を果たしているかはほ とんど分かっていない。

ヒトの好中球は成熟して血中に循環するようになると、中 性のスフィンゴ糖脂質である LacCer を大量に発現するようにな る (2)。様々な病原微生物が LacCer に結合することが報告され ているが (3-5)、LacCer の好中球機能に扔ける役割については これまで分かっていなかった。近年、スフィンゴ糖脂質が様々 な細胞内情報伝達分子と会合し、マイクロドメインを形成して いることが明らかとなっている。実際、我々は好中球において も LacCer が Src family protein tyrosine kinase (Src-PTK) である Lyn と会合したグリコシグナルドメイン (glycosignaling domain, GSD) と呼ばれるマイクロドメインを形成し、LacCer 自身が接 着分子として機能していることを見いだしている。本稿では、 スフィンゴ糖脂質を介する情報伝達ユニットであるグリコシグ ナルドメインを中心に、スフィンゴ糖脂質がどのようにしてリ ガンド認識するかについて、さらにどのように細胞内へと情報 を伝えるかについて解説する。

\section{B. スフィンゴ糖脂質はどのような分子とどのように結合する} か?

スフィンゴ糖脂質が発見されて以来、その機能について 様々な解析がなされてきた。スフィンゴ糖脂質は主に細胞膜上 に局在することから、スフィンゴ糖脂質が受容体の働きを持っ ている可能性が検討されている。これまでに様々な分子がス フィンゴ糖脂質を受容体とする報告がなされたが、その多くは 明確な証拠を示すことができていない。その中にあって、菌体 由来の分子がスフィンゴ糖脂質結合分子となることが数多く報 告されている。もっともよく知られているスフィンゴ糖脂質に 対する結合分子は、コレラ毒素のような菌体由来の毒素である (1)。例えばコレラ毒素の B サブユニットは 5 量体を形成する ことで GM1 のクラスターと強固に結合する (6)。また、ウイル スを含む様々な病原微生物がスフィンゴ糖脂質と結合すること も報告されている(3、7-10)。しかしながらこれらの結合は病原 微生物が感染するためのターゲットとしてスフィンゴ糖脂質を 利用しているのであって、スフィンゴ糖脂質が菌体膜由来の分 子に結合することで何らかの細胞機能を発現しているという明 確な証拠は LacCer 以外得られていない。

細胞接着の関わる細胞分化段階において Le の糖鎖が大量に細胞膜上に発現されることから、 $\mathrm{Le}^{\mathrm{x}}$ を持つょう なスフィンゴ糖脂質が細胞接着に関わるのではないかと考えら れている。また、ガン化に伴って細胞膜表面のスフィンゴ糖脂 
lectins, which recognize certain sugar moieties of glycosphingolipids, and through carbohydrate to carbohydrate interactions between glycosphingolipids and their binders. Selectins and siglecs have been identified as cell adhesion molecules which recognize sugar chains of glycosphingolipids (12). However, few studies have examined how glycosphingolipids affect target cells through binding those lectins. In the case of carbohydrate to carbohydrate interactions, GM3-mediated cell adhesion was well examined (13). It has been demonstrated that cells are activated through GM3 $(14,15)$. For example, the metastatic potential of B16 cells has been demonstrated to be correlated with GM3 levels on cell surfaces of those cells, suggesting the possible development of metastasis through high expression of GM3 (16). B16 cells adhere to Gg3- with strong, LacCer-, Gb4- with weak, but not to other glycosphingolipid-coated plates (17). The same binding specificities of the carbohydrate to carbohydrate interactions through GM3 were observed not only in the liposome binding experiments but also in the quantitative experiments using surface plasmon resonance techniques (18). This type of binding is followed by the trans-interactions between carbohydrate motifs of glycosphingolipids. The binding affinity between GM3 and Gg3 is quite high, and its affinity constant is higher than those of lectins with carbohydrate epitopes.

In general, not very much attention has been paid to cell recognition through carbohydrate to carbohydrate interactions. However, newly developed analytic methods have further demonstrated the height of the specificity and intensity of the binding power between carbohydrate to carbohydrate interactions (19). Live sponge cells can recognize their own kind and form big homogeneous aggregates through the trans-carbohydrate to carbohydrate interactions based on the specific carbohydrate moiety of proteoglicans on cell surfaces. Atomic force microscopy measurements revealed equally strong adhesion forces between glycan molecules as between proteins in antibody-antigen interactions. Interestingly, $\mathrm{Ca}^{2+}$ ions are crucial in carbohydrate to carbohydrate interactions both of proteoglicans and glycosphingolipids $(19,20)$. On the molecular level, $\mathrm{Ca}^{2+}$ ions probably provide coordinating forces, though ionic forces cannot be excluded (21). These $\mathrm{Ca}^{2+}$ interactions are thought to stabilize conformations and can thereby lead to hydrogen bonds and hydrophobic interactions elsewhere in the glycans and glycosphingolipids.

\section{Glycosphingolipid-Enriched Microdomains and Glycosingnaling Domains}

Glycosphingolipids consist of hydrophobic ceramide and hydrophilic sugar chains. Glycosphingolipids have the high melting-point property, and cluster to form microdomains based on cis-interactions on plasma membrane (22). Glycosphingolipidenriched microdomains contain cholesterol, sphingomyelin and
質の発現パターンが変化することが知られており、ガン化に 伴って発現量が変化するスフィンゴ糖脂質がガン細胞の転移に 関わるともいわれている(11)。ほ乳類においてこれらのスフィン ゴ糖脂質の変化を認識する機構としては、糖鎖の特定のモチー フを認識するレクチンによる結合と、糖鎖一糖鎖相互作用によ るものがある。レクチンを介する細胞接着としては、selectin や siglec 分子のレクチン構造を介するものが同定されている (12)。 しかしながら、レクチンに結合することでスフィンゴ糖脂質を 介して標的細胞にどのようなことが起こるかについてはほとん ど調べられていない。一方、糖鎖一糖鎖相互作用に基づく細胞 接着としてはGM3 を介した接着がよく研究されている (13)。 GM3 を介して細胞は活性化されることが示されている $(14 、 15) 。$ 例えば、B16メラノーマ細胞はガン化に伴って GM3 の発現パ ターンを変化させ、GM3 を細胞膜上に大量に発現することで転 移能を獲得する可能性が示されている(16)。B16 細胞はGM3 を 介して Gg3 と非常に強く、LacCer と強く、また Gb4 と弱く結 合するが、他のスフィンゴ糖脂質とは結合しない (17)。この結 合特異性はGM3 を含むりポソームを用いた実験結果と同じで あるだけではなく、表面プラズモン共鳴法を用いて物理学的に も実証されている (18)。GM3 を介したこの結合は糖脂質が細胞 膜上で集合して作り出した糖鎖モチーフが transに相互作用する ことで行われると考えられている。GM3 と Gg3 の結合親和性 は大変高く、 $\mathrm{Kd}$ 值は糖鎖を認識するレクチンと同等である。

一般に、これまで糖鎖-糖鎖相互作用に基づく細胞認識につ いてはあまり注意が払われてこなかったが、新たな解析技術に よってその特異性の高さと結合力の強さが改めて指摘されてい る (19)。例えば、海綿のプロテオグリカンも特異的な糖鎖構造 を認識して trans の糖鎖一糖鎖相互作用でグループごとに細胞集 団を形成する。原子間力顕微鏡で測定すると、このプロテオグ リカン鎖間の結合力は抗原と抗体の結合力と同等以上の強さが あり、その特異性も細胞レベルでの実験結果と一致している。 興味深いことに、スフィンゴ糖脂質やプロテオグリカンにおけ る trans 型の糖鎖一糖鎖相互作用は $\mathrm{Ca}^{2+}$ 依存性であり、 $\mathrm{Ca}^{2+}$ が 存在しなければこれらの相互作用に基づく接着反応は認められ ない(19、20)。分子レベルでは、 $\mathrm{Ca}^{2+}$ イオンはイオン力を除外で きないとしても、恐らく配位結合力をもたらすのであろう(21)。 そのため、 $\mathrm{Ca}^{2+}$ が糖鎖の立体構造を安定化するためにスフィン ゴ糖脂質やプロテオグリカンの糖鎖間で水素結合や疎水結合を つくりだすことができるようになるのではないかと考えられて いる。

\section{C. スフィンゴ糖脂質のマイクロドメインとグリコシグナルドメ} イン

スフィンゴ糖脂質は疎水性のセラミドと親水性の糖鎖から なる分子であり、融点が高く cis 相互作用に基づいて互いに会 合し、細胞膜上でマイクロドメインと呼ばれるクラスターを形 成している (22)。スフィンゴ糖脂質に富むマイクロドメインは 
saturated fatty acid chain-contained phospholipids. Microdomains are insoluble in a detergent Triton X-100 at $4^{\circ} \mathrm{C}$, and float with associated proteins to a low density during gradient ultracentrifugation (23). Because these kinds of biochemical approaches demonstrated that microdomains contain several kinds of adhesion molecules and signal transduction molecules, microdomains are thought to mediate cell functions, and named as lipid rafts (24).However, there is no report of cell function through the glycosphingolipids in the microdomain except for GSD. Glycosphingolipids are mainly thought to modulate the functions of adhesion molecules and receptors in microdomains (Fig. 1) (12).

To metastasize, circulating cancer cells adhere to vessel wall in target tissue, and extravasate into tissues. Since B16 cells
コレステロールやスフィンゴミエリンとともに飽和のリン脂質 を多く含んでおり、 $4^{\circ} \mathrm{C}$ で中性の界面活性剂である Triton X-100 で可溶化されず、超遠心によって浮上する画分として分離され る (23)。このような生化学的方法で回収されるマイクロドメイ ンには様々な受容体や接着分子および細胞内情報伝達分子が含 まれることから、マイクロドメインを介して様々な細胞機能が 発現されると考えられ、そのような情報伝達ユニットをリピッ ドラフトとも呼んでいる (24)。しかしながら、マイクロドメイ ン中のスフィンゴ糖脂質を介した細胞機能の報告はGSD以外に はなく、スフィンゴ糖脂質はもっぱらマイクロドメインに会合 している他の受容体や接着分子の機能を調節する分子として働 いていると考えられている (図 1) (12)。

ガン細胞が転移するためには、ガン細胞は標的組織の血管

A

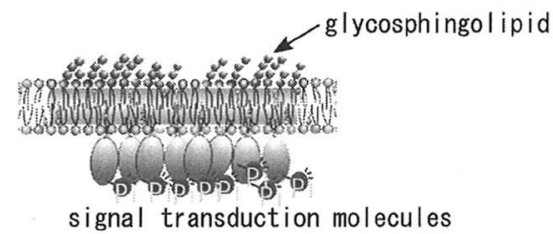

B

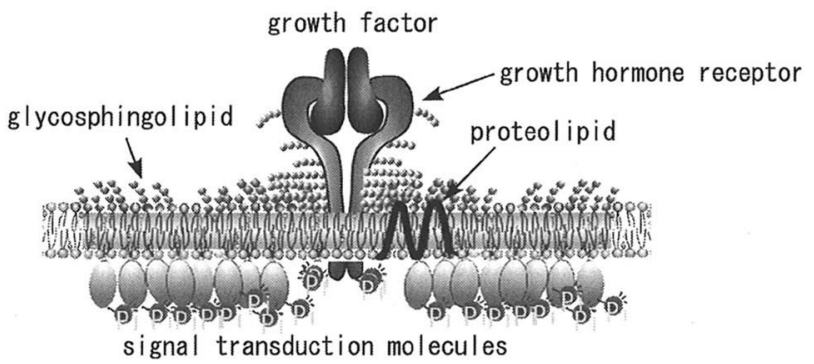

C

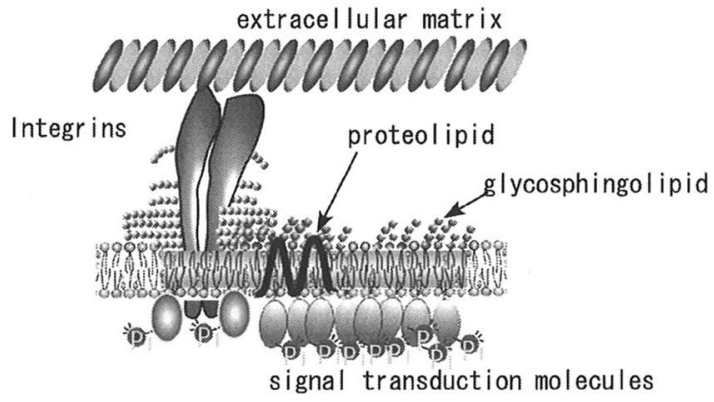

Fig.1. Schematic models of glycosphingolipid-related signal transduction units. Glycosignaling domains. Glycosphingolipds are clustered with sphingomyelin and cholesterol inserted via ceramide into the outer leaflet of the membrane. GSL clusters organized with signal transducers, which are located at the inner leaflet of plasma membrane. (B) Growth hormone receptors. When EGF-R is located in a GSL-rich domain, signaling through growth factor (EGF) to activate tyrosine phosphorylation is blocked by the association of EGF-R with GM3. Binding of GM3 to EGF-R may result from the interaction of GM3 with carbohydrate N-linked to EGF-R, as suggested by a previous study $(48,49)$. (C) Integrin receptors. N-glycosylation of integrin receptors plays an important role in connection and stabilization of integrin complex(50). The complex of GM3 with or without tetraspanin (proteolipid) molecules regulates integrin receptor functions $(51,52)$. 

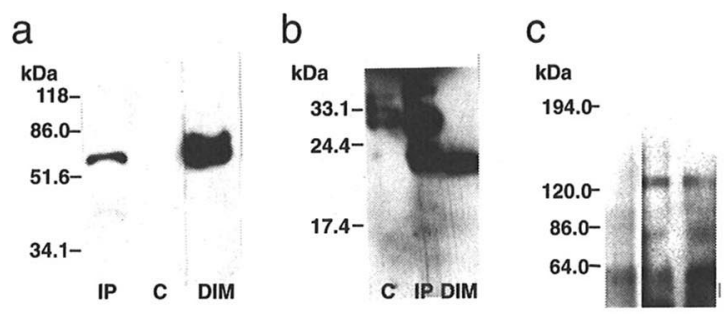

\section{B}

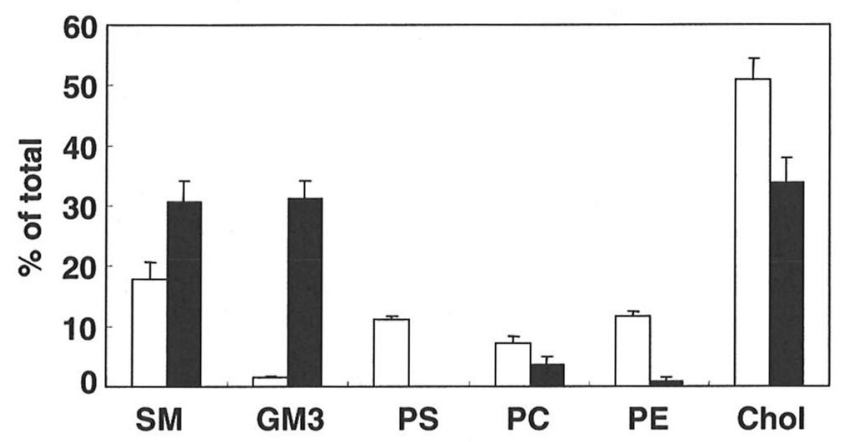

Fig. 2. Molecular composition of GM3-enriched glycosignaling domain. (A) GM3 was associated with c-Src, Rho-A and FAK. The low density, detergent-insoluble membrane fraction (DIM, microdomain fraction) was co-immunoprecipitated with anti-GM3 antibody. The bound materials were Western blotted using anti-cSrc (a), anti-Rho-A (b), or anti-FAK (c) antibodies. IP immunoprecipitates with anti-GM3 antibody; C, with control mouse antibody. (B) Lipid composition of DIM and GM3enriched GSD immunoseparated from DIM. Lipid composition of DIM isolated from B16 cells (open bars), composition of GM3- and c-Src-containing fraction (corresponding to GSD) immunoseparated from DIM by anti-GM3 antibody (closed bars). Total lipids of reconstituted membrane were extracted, and the composition was determined. Each bar shows the mean \pm S.D. of 3 experiments. PS, phosphatidylserine; PC, phosphatidylcholine; PE, phosphatidylethanolamine; Chol, cholesterol.

adhere to endothelial cells, there is a possibility that B16 cells receive extracellular signaling and activate through GM3, leading to protease release and migration. Actually, we found that the GM3-enriched microdomain, which were immunoprecipitated from detergent insoluble membrane fraction of B16 cells, contain several signal transduction molecules such as cSrc (Fig. 2A) (14). These GM3-associated transducer molecules are activated through GM3. These data indicate that the binding of GM3 with ligands such as Gg3 causes activation of GM3-associated signal transduction molecules. Thus, the glycosphingolipid-enriched microdomain, involved in cell adhesion and capable of sending signals through glycosphingolipids associated with membrane-bound signal transduction molecules, is termed the "glycosphingolipid signaling domain" or "glycosignaling domain" (GSD) (Fig. 1) (25). In contrast, lipids of GM3-enriched GSD in B16 cells are mainly composed of GM3, sphingomyelin, and cholesterol (Fig. 2B). Phospholipids are minor compo-
壁に先ず接着した後、血管外へと遊走する必要がある。マウス メラノーマB16 細胞は GM3 を介して流血中で血管壁に接着で きることから、B16 細胞は GM3 を介して細胞内に情報を伝達 し細胞を活性化し、プロテアーゼの放出や遊走を引き起こして いる可能性がある。実際、我々はB 16 細胞からマイクロドメイ ンを調製し、そこから GM3 を主な構成成分とするドメインを 分離すると、cSrc などの様々な細胞内情報伝達分子が GM3 と 会合していることを見いだした(図 2A) (14)。これらの情報伝達 分子は GM3 を介して活性化されることから、B16 細胞は GM3 に Gg3 などのリガンドが結合することでマイクロドメインとし て会合している細胞内情報伝達分子を活性化し、細胞内に情報 が伝達される。そこで、スフィンゴ糖脂質がSrc-PTKを中心と した膜結合型の細胞内情報伝達分子と会合したマイクロドメイ ンで、スフィンゴ糖脂質を介して細胞内に情報を伝達するドメ インを GSD (glycosignaling domain, glycosphingolipid signaling domain) と名付けた (図 1) (25)。Triton X-100 不溶性画分として 得られる B16 細胞のマイクロドメインにおける GM3 は脂質全 


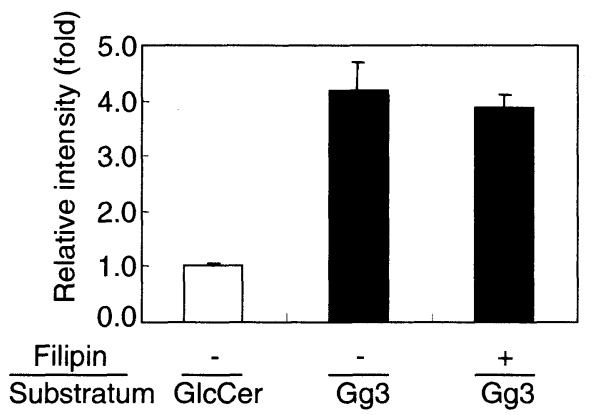

B

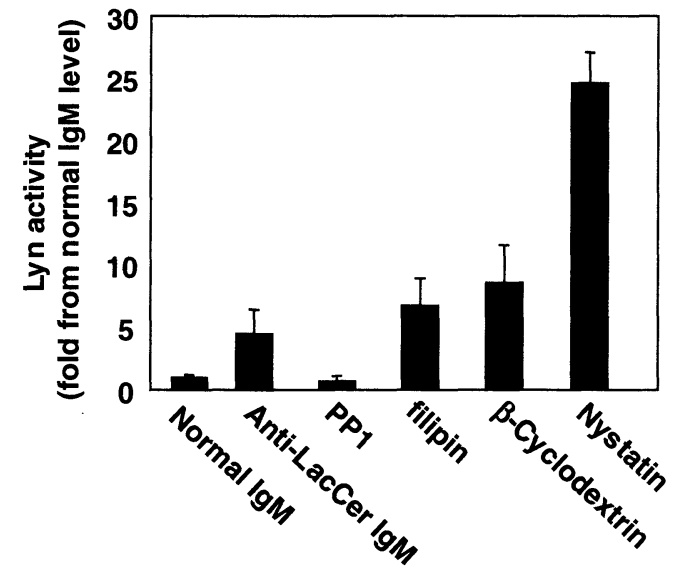

Fig. 3. Cholesterol-depleting reagents do not inhibit GSD-mediated signal transduction. (A) Effects of filipin on FAK activity induced by $\mathrm{Gg} 3$. B16 cells were pretreated with $0.5 \mu \mathrm{g} / \mathrm{ml}$ filipin at $37^{\circ} \mathrm{C}$ for $30 \mathrm{~min}$ and then added to a $\mathrm{Gg} 3$-coated dish (gray bar). Tyrosine phosphorylation of FAK was analyzed by immunoprecipitation with anti-FAK rabbit IgG followed by Western blotting with anti-phosphotyrosine mAb PY20 and quantified. (B) Effects of filipin, cyclodextrin and nystatin on antiLacCer antibody-induced Lyn activation. DIM prepared from neutrophil plasma membrane was diluted and incubated without or with $0.5 \mu \mathrm{g} / \mathrm{ml}$ filipin (filipin), $10 \mathrm{mM}$ methyl- $\beta$-cyclodextrin (B-Cyclodextrin) or $60 \mu \mathrm{g} / \mathrm{mL}$ nystatin (Nystatin) for $30 \mathrm{~min}$ at $25^{\circ} \mathrm{C}$. After incubation, the reaction mixtures were ultracentrifuged, and the pellets were resuspended in $5 \mathrm{~mL}$ of the kinase buffer, followed by incubation in normal IgM- or anti-LacCer IgM T5A7-coated dishes for $15 \mathrm{~h}$ at $4^{\circ} \mathrm{C}$. Then, an aliquot of $50 \mu \mathrm{Ci} \gamma^{32} \mathrm{P}-$ ATP was added to each dish, and the mixture was further incubated at $37^{\circ} \mathrm{C}$ for $5 \mathrm{~min}$. In some experiments, anti-LacCer-induced Lyn activation was assessed in the presence of $100 \mathrm{nM}$ PP1 (PP1).

nents of lipids in GM3-enriched GSD. Enrichment of glycosphingolipids in microdomains is one of the features of GSD. It has been demonstrated that cholesterol depletion from microdomains by treatment with methyl- $\beta$-cyclodextrin generally causes disruption and dysfunction of those domains. It has been indicated that the structure of the microdomains is broken by removing the cholesterol in the as one of the features of the microdomain generally, and damages the function through the microdomain. On the other hand, methyl- $\beta$-cyclodextrin does not affect the association of glycosphingolipids with Src-PTK in GSD, and rather enhances the activities of Src-PTK through glycosphingolipids (Fig. 3) (2,25). These data clearly indicate that the molecular mechanisms of GSD-mediated signal transduction are completely different from those of other microdomains.
体の $2 \%$ 程度にすぎず、リン脂質とコレステロールが大量に存 在している。一方、B16 細胞の GM3 の GSD を構成する脂質は 主にGM3、スフィンゴミエリンとコレステロールからなってお り、リン脂質はあまり含まれていない(図 2B)。このように、 GSD の脂質構成の特徵は中心となるスフィンゴ糖脂質の存在比 が非常に高いことである。一般にマイクロドメインの特徵の一 つとして、メチル $\beta$ シクロデキストリンでコレステロールを取 り除くとマイクロドメインの構造が壊れ、マイクロドメインを 介した機能が損なわれる。しかしながら、GSDはメチル $\beta$ はク ロデキストリンを加えてもスフィンゴ糖脂質と Src-PTK との会 合は壊れず、スフィンゴ糖脂質を介した情報伝達は影響されな いかむしろ増強される(図 3) (2、25)。このことはGSD の構造と シグナル伝達機構が他のマイクロドメインの場合とは大きく異 なっていることを示している。 


\section{GSD-Mediated Neutrophil Functions}

When pathogenic microorganisms infect a body, circulating neutrophils immediately extravasate toward the microorganisms and phagocytose them to kill them (26). To recognize microorganisms, neutrophils express on cell surfaces several kinds of adhesion molecules for bacteria such as complement receptor, Fc receptors, LPS binding receptors and $\beta$-glucan re-

\section{D. 好中球の GSD を介した機能}

病原微生物が身体に侵入すると、好中球は速やかに病原体 に向かって遊走し、それらを貪食することで排除を試みる (26)。そこで、病原微生物を認識するために好中球は補体レセプ ター、Fcレセプター、LPS レセプターあるいは $\beta$ グルカンレセ プターなど様々な接着分子を細胞膜表面に発現している。好中 球の貪食反応には大きく分けてオプソニン依存性と非依存性の

A

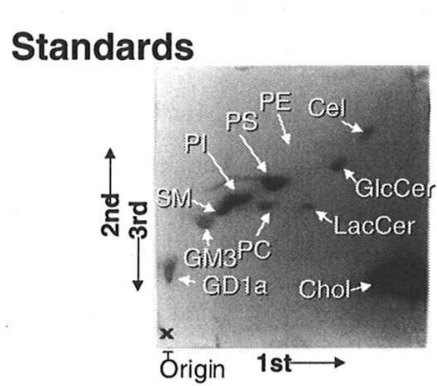

DIM

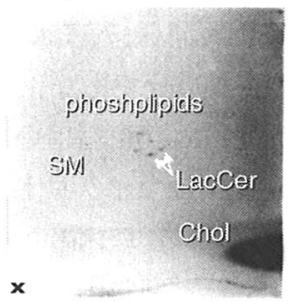

Neutrophils
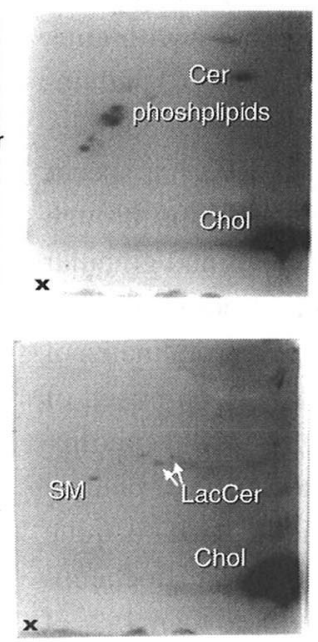

\section{Anti-LacCer}

$\lg M$

B

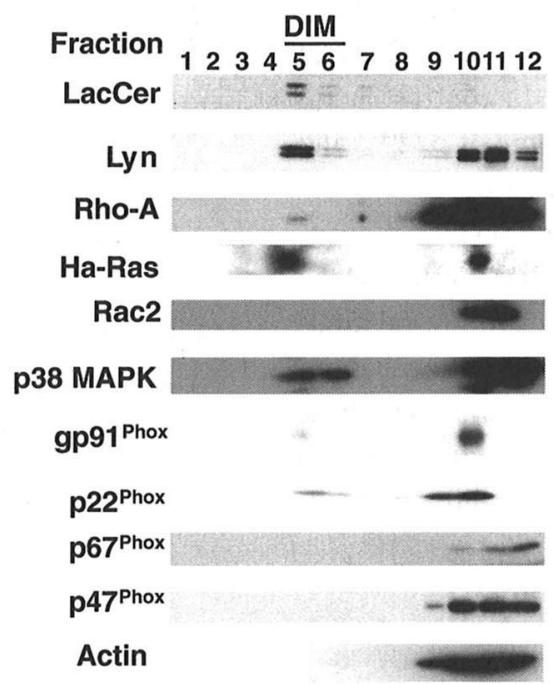

Fig. 4. Molecular composition of LacCer-enriched glycosignaling domain. (A) Two-dimensional HPTLC analysis of lipid components in DIM fractions of neutrophils. Lipids compositions of neutrophils were analyzed by two-dimensional HPTLC, and TLC plates were sprayed with primulin. Lysates, whole cell lysates of neutrophils; DIM, fraction 5; Anti-LacCer IgM, immunoprecipitated fraction of DIM with anti-LacCer Huly-m13; Standards, standard lipids. PE, phosphatidylethanolamine; PS, phosphatidylserine; PC, phosphatidylcholine; PI, phosphatidylinositol; LacCer, lactosylceramide; GlcCer, glucosylceramide , Cer, ceramide; SM, sphingomyelin; Chol, cholesterol. (B) Distribution patterns of LacCer, transducer molecules and NADPH oxidase components in fractions separated by sucrose density gradient centrifugation. Neutrophils were lysed in the Triton X-100 containing lysis buffer, homogenized, and subjected to sucrose density gradient centrifugation. A series of $1 \mathrm{~mL}$ fractions were taken starting from the top, and subjected to HPTLC (LacCer) or SDS-PAGE/immuno blotting (transducer molecules, NADPH oxidase components and actin), respectively. 
ceptors. Neutrophils phagocytose microorganisms through opsonin-dependent and -independent mechanisms (26). Opsoninindependent phagocytosis is speculated to be mainly mediated by adhesion molecules for the bacterial cell wall components such as LPS and $\beta$-glucan. It has been demonstrated that poly $\beta 1-6$ glucotriosyl- $\beta 1-3$ glucopyranose (PGG) glucan selectively binds to LacCer of neutrophils (10). PGG glucan enhances neutrophil superoxide generation and NF- $\mathrm{\kappa B}$ activity. LacCer has been demonstrated to specifically recognize several kinds of pathogenic microorganisms such as Escherichia coli, Boredetella pertussis, dysentery bacillus, Helicobacter Pylori, and candida albicans (3-5). Moreover, cross linking of LacCer with antiLacCer antibodies induces superoxide generation (10) and upregulation of $\mathrm{CD} 11 \mathrm{~b} / \mathrm{CD} 18$ (Mac1) which serves as a complement receptor for $\mathrm{C} 3 \mathrm{bi}$ in neutrophils (27). Therefore, it is speculated that neutrophils possess microbicidal mechanisms through LacCer. LacCer is localized in plasma membranes and granular membranes, and biochemically isolated in microdomains (2). LacCer-enriched GSD, which is isolated from microdomains of neutrophils by anti-LacCer antibody, is mainly composed of LacCer, sphingomyelin and cholesterol (Fig. 4A). Phospholipids are minor components of LacCer-enriched GSD of neutrophils. The lipid composition of LacCer-enriched GSD is quite similar to that of GM3-enriched GSD in B16 cells. Biochemical analysis using Triton X-100 revealed that more than $95 \%$ of LacCer in the cell lysates was recovered in microdomains, which only contained $2.5 \%$ of total cellular protein (Fig. 4B). Under these conditions, signal transducer molecules Lyn, Ha-Ras and p38 MAPK were enriched in microdomains. In contrast, actin was localized in the high-density fraction. Some of $\mathrm{p} 22^{\text {phox }}$ and gp $91^{\text {phox }}$, membrane components of NADPH oxidase, were recovered in microdomains, whereas $\mathrm{p} 47^{\text {phox }}$ and $\mathrm{p} 67^{\text {phox }}$, cytosolic components of NADPH oxidase, and small G-protein Rac2 were recovered in high-density fractions. There are several kinds of Src-PTK in neutrophils (28); in particular, Lyn has been demonstrated to play a crucial role in superoxide generation in these cells (29). In mature neutrophils, Lyn is localized only in plasma membrane (Fig. 5), and activated by anti-LacCer antibody treat-
二つの機構がある (26)。その中でオプソニン非依存性の貪食機 構は主に菌体壁成分に対する接着分子を介して行われていると 考えられている。これまでに可溶性の $\beta 1-6$ 分岐の $\beta 1-3$ グルカ ン (PGGグルカン) が好中球の LacCer とオプソニン非依存的に 結合することが報告されている (10)。PGG グルカンは好中球の 活性酸素の産生を高め、NFKB 活性を上昇させる。さらに、大 腸菌、百日咳菌、赤痢菌、ヘリコバクターピロリ菌、カンジダ など幅広い菌が LacCer と選択的に結合することが示されている (3-5)。抗 LacCer 抗体で LacCer を架橋すると、好中球は活性酸 素を産生したり (10)、補体の C $3 b i$ に対するレセプターである $\mathrm{CD} 11 \mathrm{~b} / \mathrm{CD} 18$ (Mac1) の発現を上昇したりする (27)。したがっ て、好中球は LacCer を介した貪食・殺菌機構を持っていると考 えられている。好中球の LacCer は細胞膜と顆粒膜に存在する が、すべての LacCer は生化学的にはマイクロドメインとして回 収される (2)。抗 LacCer 抗体を用いて分離した LacCer に富む マイクロドメイン画分の脂質の構成成分は、B16 細胞の GM3 の GSD と同様に、LacCer、スフィンゴミエリン、コレステロール が主な成分であり、リン脂質はあまり含まれていない(図 4A)。 Triton X-100 を用いた生化学的な解析を行うと、 $95 \%$ 以上の LacCer はマイクロドメイン画分に回収されるが、この画分には タンパク質全体の $2.5 \%$ しか含まれない (図 4B)。このような条 件下で、細胞内情報伝達分子である Lyn, Ha-Ras と p38 MAPK がマイクロドメイン画分に局在している。一方、アクチンは高 密度側の画分に局在する。活性酸素産生酵素である NADPH oxidase の膜成分である $22^{\text {phox }}$ と gp91 phox の一部はマイクロドメイ ン画分に存在するが、細胞質成分である $47^{\text {phox }}$ と p $67^{\text {phox }}$ および 低分子量 $\mathrm{G}$ タンパク質 Rac2 は高密度側の画分に回収される。 好中球には様々な Src ファミリーの分子が存在しており (28)、 中でも Lyn は活性酸素の産生に重要な役割を果たしていること が示されている (29)。好中球の Lyn はすべて細胞膜に局在して 㧍り (2)、抗 LacCer 抗体で処理すると好中球の Lyn が活性化さ れ (図 6A)、Src-PTK の特異的阻害剤である PP1 で LacCer を介 したLynの活性化が阻害されるとともに活性酸素の産生も抑え

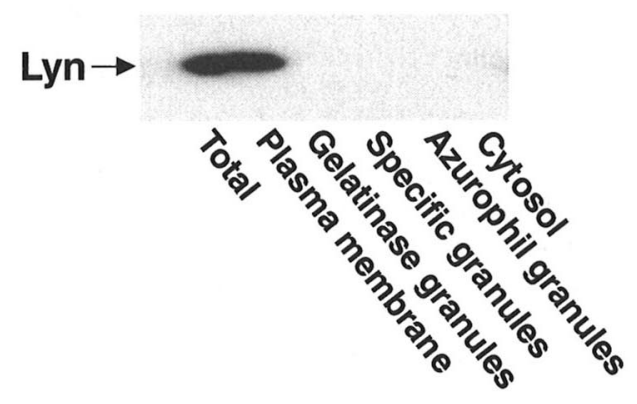

Fig. 5. Subcellular localization of Lyn. Subcellular fractionation of neutrophils was performed by Percoll centrifugation techniques, and azurophil, specific, gelatinase granules and plasma membrane containing secretory vesicles were obtained. Lyn molecules in each fraction were identified by Western blotting. 
ment (Fig. 6A). A Src-PTK inhibitor PP1 inhibits not only Lyn activation but also superoxide generation by anti-LacCer antibody treatment. These data suggest that neutrophils have LacCerenriched glycosignaling domain coupled with Lyn on plasma membrane, and that ligands binding with LacCer causes Lyn activation through LacCer in GSD, resulting in superoxide generation from neutrophils. Several kinds of LacCer-enriched GSDassociated proteins were phosphorylated by anti-LacCer antibody, and the phosphorylation was completely inhibited by PP1 (Fig. 6). Lyn-associated neutrophil superoxide generation has
られる。これらのことは、好中球には LacCerに富むマイクロド メインが GSD として機能していて、LacCer に対するリガンド が LacCer に結合すると、Lyn が活性化され、活性酸素が産生さ れることを示している。抗 LacCer 抗体で処理することでLacCer に富むマイクロドメインに含まれる様々なタンパク質がリン酸 化され、PP1 処理によってすべてのタンパク質のリン酸化が完 全に抑制される (図 6)。好中球の Lyn を介した活性酸素の産生 は、Lyn が活性化されることで p38 MAP kinase と protein kinase C が活性化され、NADPH oxidase の細胞質因子である p47phox が

A

Autoradiogram Western blot

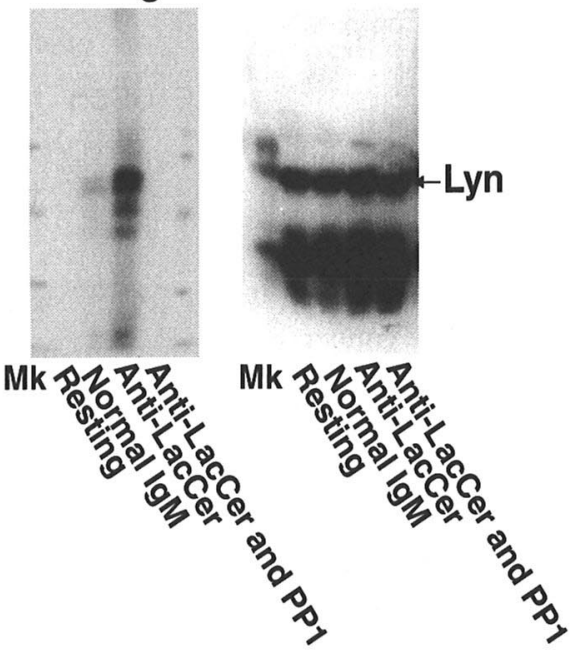

B

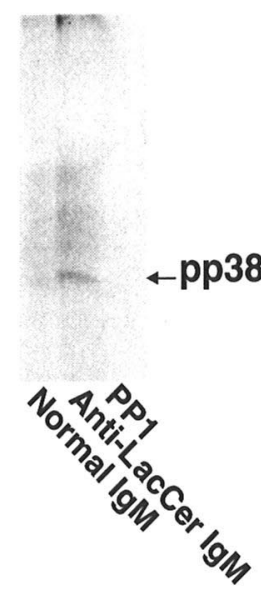

Fig. 6. T5A7-induced phosphorylation of Lyn and p38 MAPK in DIM. DIM isolated from neutrophils was kept on ice in a polypropylene tube (Resting), or placed in normal IgM- (Normal IgM), or anti-LacCer IgM T5A7-coated dishes (AntiLacCer IgM) at $4^{\circ} \mathrm{C}$ for $15 \mathrm{~h}$. Then, the mixtures were incubated with $\gamma$-32P-ATP in the absence or presence of $100 \mathrm{nM} \mathrm{PP} 1$ for 5 min at $37{ }^{\circ} \mathrm{C}$, followed by TCA precipitation. (A) The TCA precipitate was immunoprecipitated with mouse anti-Lyn mAb, and subjected to SDS-PAGE, electroblotting transfer and autoradiography (Autoradiogram). To evaluate the recovery of Lyn, the blotted membrane was probed with rabbit anti-Lyn IgG (Immunoblot). (B) The TCA precipitate was immunoprecipitated with mouse anti-pp38 MAPK mAb, and subjected to SDS-PAGE, electroblotting and autoradiography. 
been demonstrated to be mediated via p38 MAP kinase and protein kinase $\mathrm{C}$; then cytosolic components of NADPH oxidase $\mathrm{p} 47^{\text {phox }}$ and $\mathrm{p} 67^{\text {phox }}$ translocate to the membrane cytochrome b558, and form the catalytically active complex (30). It has been reported that, in neutrophils, activated Lyn associates with $\mathrm{PI}_{3} \mathrm{~K}$ for the activation of $\mathrm{PI}_{3} \mathrm{~K}(31,32)$. $\mathrm{PI}_{3} \mathrm{~K}$ is believed to regulate the activation of $\mathrm{p} 38$ MAPK and protein kinase $\mathrm{C}$, which results in the activation of NADPH oxidase $(33,34)$. PP1 and PI $\mathrm{K}$ inhibitor wortmannin completely inhibited the anti-LacCer antibody-induced superoxide generation by neutrophils (2). A p38 MAPK inhibitor SB203580 and protein kinases C inhibitor H7 partially inhibited the anti-LacCer antibody-induced superoxide generation from neutrophils. It seems, therefore, that the ligands binding to LacCer in GSD induce the activation of Lyn/ $\mathrm{PI}_{3} \mathrm{~K} / \mathrm{p} 38 \mathrm{MAPK} /$ protein kinase $\mathrm{C}$ signal transduction pathway leading to superoxide generation (Fig. 7).

\section{E. Signal Transduction Mechanisms between Glycosphingo- lipid and Lyn in GSD}

LacCers, like other glycosphingolipids, span halfway through the membrane, yet they have to transmit the signal in GSD from the outside to the inside of the cell. The connection of LacCer, located in the external leaflet of the bilayer, with Lyn, located in a cytoplasmic site of membrane, remains unclear. The same question applies to various glycosphingolipids and other Src-PTK, G-proteins, and signal transducers. Several protein kinases including Lyn have been found in microdomains, and associated with the cytoplasmic leaflet through myristylation and palmitylation (35). How does LacCer mediate the signals to

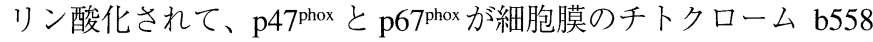
に移行することで始まる (30)。好中球において PI kinase は Lyn と会合して初めてリン酸化されることが示されている $(31$ 、32)。 また、PI kinase を介してp38 MAP kinase や protein kinase Cが活 性化されてNADPH oxidase が活性化されるといも言われている (33、34)。抗 LacCer 抗体による活性酸素産生は PP1 や PI kinase の特異的阻害剤であるwortmanninで完全に阻害されるが、p38 MAP kinase の阻害剤である SB203580 や protein kinase C の阻害 剂である H7 では部分的にしか阻害されない (2)。したがって、 LacCer にリガンドが結合すると、Lyn が活性化され、PI kinase、さらに protein kinase C と p38 MAP kinase の経路を介し て $\mathrm{p} 47^{\mathrm{phox}}$ がリン酸化されて、NADPH オキシダーゼが順次活性 化されると考えられる (図 7)。

\section{E. GSD におけるスフィンゴ糖脂質から Lyn への情報伝達機構}

LacCer は他のスフィンゴ糖脂質同様に、細胞膜の途中まで しか入っていないが、細胞外から細胞内へと GSDに扔いて情報 を伝達しなければならない。細胞膜の外側の層に存在する LacCer が細胞膜の内側の層に存在するLyn とどのようにつな がっているかは未だに良く分かっていない。同様の疑問は他の スフィンゴ糖脂質と Src-PTK や G タンパク質、情報伝達分子で もいうことができる。Lyn を含吉様々な細胞内情報伝達分子は パルミトイル化やミリストイル化によって細胞膜の内側に結合 している (35)。それでは、GSDにおいて脂質二重層の外側にあ るスフィンゴ糖脂質が内側にある Src ファミリー分子にどのよ うにして情報を伝えているのであろうか。細胞膜は脂質二重層

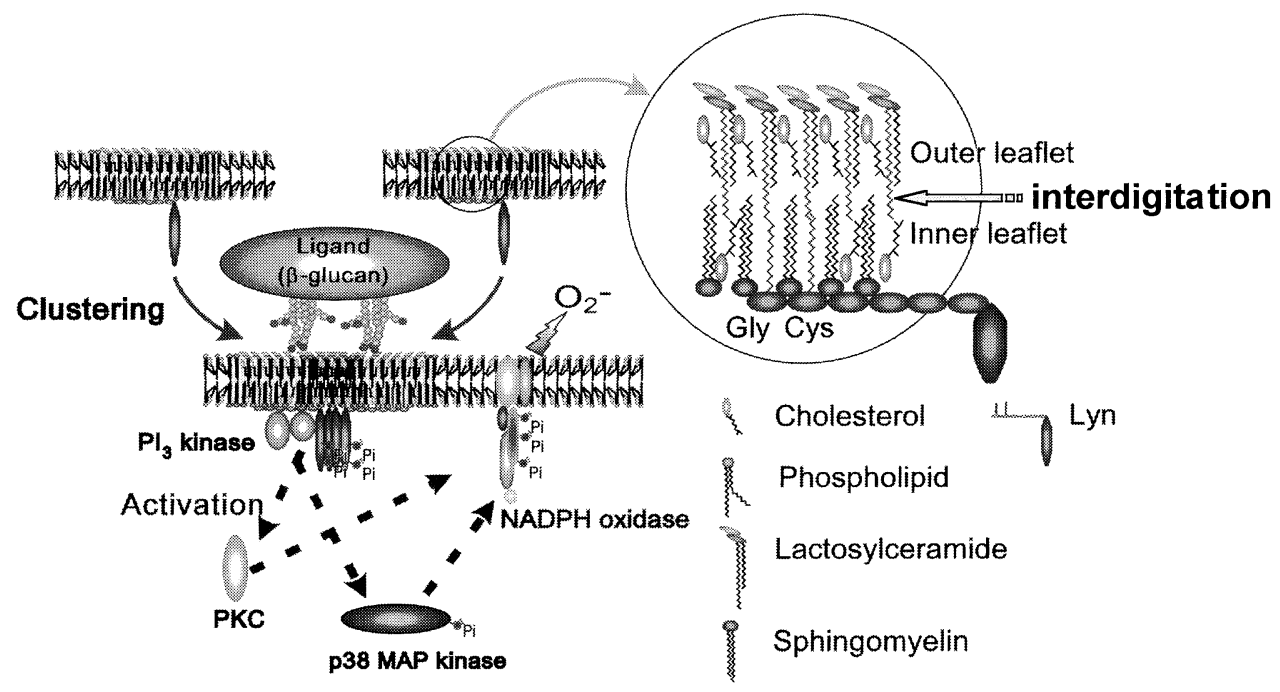

Fig. 7. Signal transduction cascade of LacCer-enriched GSD in neutrophils. Neutrophil LacCer-enriched GSD is mainly composed of LacCer, sphingomyelin phospholipids and cholesterol. LacCer is closely associated with Lyn in GSD. It seems that the binding of microorganisms to LacCer induces the clustering of LacCer-enriched GSD, leading to superoxide generation through Lyn-, $\mathrm{PI}_{3} \mathrm{~K}-$-, p38 MAPK-, and protein kinase C-dependent signal transduction pathway. It seems that long fatty acid-chain contained-LacCers may interdigitate into the inner leaflet, and play an important role in signal transduction at LacCer-enriched GSD from outside to inside of the cells. 
Lyn molecules? Plasma membrane consists of a lipid bilayer The fatty acid side chains of the phospholipids present in microdomains tend to be more highly saturated than those in the surrounding membrane. This allows close packing with the saturated acyl chains of glycosphingolipids and probably leads to phase separation. Due to the presence of cholesterol, a liquid ordered domain is formed exhibiting less fluidity than the surrounding plasma membrane (36). This tight packing of lipids and phase separation is probably responsible for the signature property of microdomains (37). Regardless of the structural variations of the carbohydrate moieties, glycosphingolipids have a common minimum-energy conformational structure in which the oligosaccharide chain is oriented at a defined angle to the axis of ceramide (12). Those physical properties lead to form extensive clusters separated from glycerophospholipids and some types of glycoprotein clusters in the plasma membrane. Flow cytometric analysis revealed that Lyso-GM3, which is composed of sphingosine instead of ceramide, markedly diminished the reactivity of anti-GM3 antibody on B16 cells (38). The reactivity of anti-GM3 antibody was found only on plasma membrane with high GM-density $(22,39)$. For instance, in human mononuclear cells, no significant staining patterns using immunofluorescent-conjugated anti-LacCer were observed in confocal microscopic analysis (Fig. 8), although those cells are believed to express LacCer on cell surface (40). Therefore, similar to the reactivity characteristic of anti-GM3 antibody, it seems that the reactivity of anti-LacCer antibody depends on the LacCer-density on cell surface. Lyso-GM3 diminished the GM3-mediated functions of B16 cell $(25,38)$. Thus, it can be speculated that
からなっている。マイクロドメイン中では飽和の脂肪酸鎖を持 つリン脂質が周囲の膜よりも多く、そのため飽和の脂肪酸鎖を もつスフィンゴ糖脂質をよりパックしてクラスターを形成する ことで周囲の膜から区別する (36)。この強固なりピッドの固ま りと相分離がマイクロドメインを作り出していると考えられて いる (37)。糖鎖構造の多様性によらず、スフィンゴ糖脂質はセ ラミド軸に対して一定の角度を持っており、各糖鎖はもっとも 安定な立体構造をとる (12)。そのためスフィンゴ糖脂質はこれ らの物理学的な特性によって細胞膜上で他の糖リン脂質や糖夕 ンパク質から完全に分かれたクラスターを作っている。セラミ ド部分をスフィンゴシンに置き換えた Lyso-GM3 は B16 細胞の フローサイトメトリー上での抗 LacCer 抗体の反応性を著明に減 弱させることが示されている $(25 、 38)$ 。抗 GM3 抗体は、GM3 が 一定の大きさのクラスターを形成していないと反応しない $(22 、$ 39)。例えば、単核球は LacCer 老細胞表面に発現しているとい

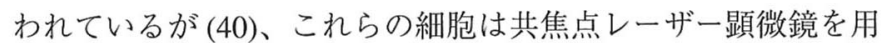
いた観察では抗 LacCer 抗体で有意に染色することができない (図 8)。このことは抗 LacCer 抗体も抗 GM3 抗体と同様の性質 を持っていることを示している。Lyso-GM3 をB16 細胞に加え ると、B16 細胞の GM3 に富む GSD を介した情報伝達分子の活 性化と細胞機能が抑制される $(25 、 38)$ 。抗 GM3 抗体は、GM3が 一定の大きさのクラスターを形成していないと反応しない (22、 39)。Lyso-GM3 が膜に取り込まれたことで、GM3 の cis 相互作

\section{Neutrophils}

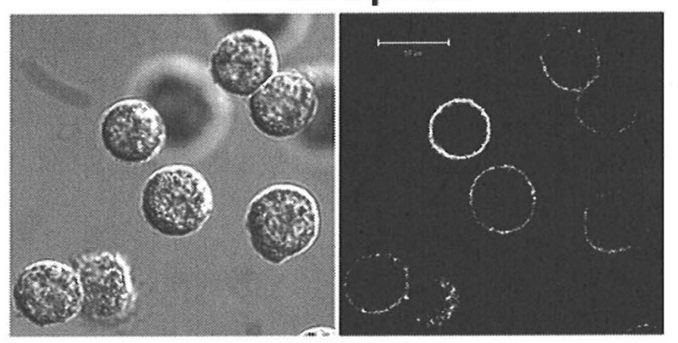

Mononuclear cells

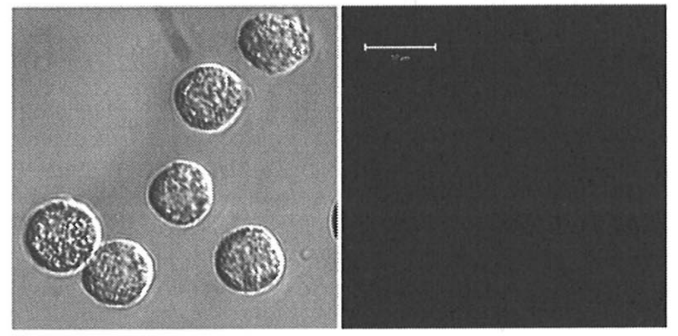

Fig. 8. Immunofluorescence staining of leukocytes with LacCer. Human neutrophils and mononuclear cells were stained with Alexa546-conjugated anti-LacCer mAb, and examined with a Zeiss LSM 510 confocal microscope equipped with a Plan-Apochromat x100 oil DIC objective. a, Immunofluorescence images; b, Nomarski images. 
Trends in Glycoscience and Glycotechnology Vol.17 No.93 (January 2005) pp.1-14

Lyso-GM3-induced destruction of GM3 cis-interaction collapses GM3 clusters (microdomains), resulting in dysfunction of GM3enriched GSD-mediated functions of B16 cells.

When promyelocytic leukemia HL-60 cells were differentiated into neutrophilic lineage by dimethylsulfoxide (DMSO)treatment, they acquired superoxide generating activity. Although DMSO-treated HL-60 cells express LacCer on cell surface as well as on neutrophils, they did not generate superoxide anion by anti-LacCer antibodies. Lyn molecules were not recovered in the LacCer-enriched microdomains isolated from plasma membrane of DMSO-treated HL-60 cells (2). Moreover, Lyn molecules of DMSO-treated HL-60 cells were not phosphorylated by anti-LacCer antibodies. These data indicate that, DMSOtreated HL-60 cells do not form LacCer-enriched GSD coupled with Lyn. Then, why is LacCer not able to be associated with Lyn molecules in HL-60 cells? The ceramide structures are various in cell types. In human neutrophils, ceramide consists of d18 sphingosine and C16- to C24- fatty acids. It seems most possible that interdigitation of long-chain LacCer into the opposing membrane leaflet could lead to the preferential binding of LacCer to acyl chains of Lyn (Fig. 7). LacCer molecules of neutrophils have been reported to possess $\mathrm{C} 24$ acyl chains $(41,42)$. In vitro experiments using artificial membrane demonstrated that the methyl end of the $\mathrm{C} 24$ fatty acid of LacCer in a bilayer of host matrix crosses the hydrophobic membrane center and interdigitates with fatty acids of phospholipids and affects the fluidity of the opposing monolayer $(41,42)$. Cross-linking experiments using cerebellar granule cells with a photoactivable, radioactive GD1b derivative show that $\mathrm{c}-\mathrm{Src}$ and Lyn associate directly with GD1b (43). Src family kinases are auto-phosphorylated by gathering themselves (44). Cross-linking of LacCer by anti-LacCer antibody was able to induce LacCer-mediated signaling. Thus, the clustering of LacCer at exoplasmic leaflet may activate the cytoplasmic Lyn molecules via the interaction between acyl chains of these molecules (Fig. 7).

\section{F. Future Direction}

Now, the concept of "lipid rafts" in itself seems to slide into chaos (45). The main reason is that the microdomains have to be biochemically isolated and characterized using neutral detergents such as Triton X-100. Moreover, there are several kinds of microdomain-isolation methods; concentrations of Triton X-100 in reports about microdomains are different from each group (46). Therefore, the real structure and functions of microdomains still remain unclear. In particular, nobody knows the real domain size of microdomain in living cells (19). Moreover, how microdomains can achieve such signaling remains unknown (47). It has been demonstrated that glycosphingolipids regulate the functions of adhesion molecules and receptors through the (supra-) biomolecular complex formation of
用が妨げられて、GM3 のクラスター形成が阻害され、B16 細胞 はGM3 を介した c-Src 等の活性化や接着反応が起こらなくなっ たと考えられる。

前骨髄性白血病細胞株である HL-60 細胞は DMSO 存在下 で培養することで好中球系細胞に分化し、活性酸素を産生する ようになる。HL-60 細胞は細胞膜上に LacCer を好中球と同程度 発現しているにもかかわらず、抗 LacCer 抗体を介しては活性酸 素を産生することができない。HL-60 細胞の細胞膜から分離し た LacCerに富むマイクロドメインにはLyn が含まれておらず、 抗 LacCer 抗体で処理した HL-60 細胞の Lyn 分子はリン酸化さ れない (2)。それでは、なぜ HL-60 細胞では LacCer と Lyn は会 合しないのであろうか。セラミドの構造は組織や細胞によって 様々であるが、ヒト好中球のセラミドは炭素数18のスフィンゴ シンと炭素数 16 から 24 の脂肪酸鎖からなっている。最も可能 性があると筆者らが考えているのは、外側の脂質層にある LacCerの脂肪酸鎖が内側の脂質層に突き出して、直接 Lynの脂 肪酸鎖と相互作用するという考え方である (図 7)。人工膜を使っ た実験によれば、少なくともC24 の脂肪酸鎖を持つスフィンゴ 糖脂質は脂質二重層の反対側の層に常に突き出して、反対側の 層の流動性に影響を与えられることが示されている $(41 、 42) 。 ま$ た、GD1b がc-Src や Lyn と直接結合できることを光感受性架 橋剤とアイソトープ標識した GD1b を用いて小脳顆粒細胞で示 されている (43)。Src-PTK は互いに集合した状態になることで 活性化される (44)。リガンドが LacCerに結合すると、LacCerの クラスターがさらに凝集して大きな GSD クラスターを形成し、 LacCer 分子が集合するとともに細胞の内側の Lyn 分子が集合し て互いにリン酸化することで、細胞内に情報が伝わるのではな いだろうか(図 7)。

\section{F. 今後の展望}

最近になって、いわゆるリピッドラフトの概念そのものが 混沌としている (45)。その主な理由として、マイクロドメイン の精製や機能解析などの生化学的な解析手段に Triton X-100 等 の中性界面活性剂を用いている点が挙げられる。グループに よって異なる濃度の Triton X-100を用いて研究を進めたりする ため (46)、マイクロドメインが実際にどのような構造で、どの ような機能に関与しているかがはっきりとしない。特に、マイ クロドメインを構成する分子のクラスターがどの範囲まで及ぶ かが明確でない(19)。また、マイクロドメインに抏いてどのよ うに情報が細胞外から細胞内へと伝達されているかは今もって

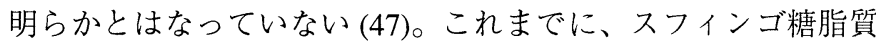


Trends in Glycoscience and Glycotechnology Vol.17 No.93 (January 2005) pp.1-14

glycosphingolipid-enriched microdomains with those molecules. There is a possibility that, in such biomolecular complexes, glycosphingolipids form GSD and the binding of glycosphingolipids with ligands may transmit outside information into cells to affect the association of molecules in the complexes, and then those complexes-mediated cell functions would occur. It remains a significant challenge to reveal the actual functions and mechanisms of those complexes.
が他の接着分子や受容体と超分子複合体を形成することで、他 の分子を介した生物機能を調節することが示されつつある。超 分子複合体においてスフィンゴ糖脂質がGSDを形成し、GSDを 介して情報が細胞内に入ることによって他の分子の会合に影響 を与え、結果として超分子複合体を介して細胞機能が発現され る可能性もある。いかにこれら複合体の真の姿を明らかにする かが今後の重要な課題である。

\section{References}

1. Hakomori, S. (2003) Curr. Opin. Hematol. 10, 16-24

2. Iwabuchi, K., and Nagaoka, I. (2002) Blood 100, 1454-1464

3. Angstrom, J., Teneberg, S., Milh, M. A., Larsson, T., Leonardsson, I., Olsson, B. M., Halvarsson, M. O., Danielsson, D., Naslund, I., Ljungh, A., Wadstrom, T., and Karlsson, K. A. (1998) Glycobiology 8, 297-309

4. Karlsson, K. A. (1989) Annu. Rev. Biochem. 58, 309-350

5. Saukkonen, K., Burnette, W. N., Mar, V. L., Masure, H. R., and Tuomanen, E. I. (1992) Proc. Natl. Acad. Sci. USA 89, 118-122

6. Lesieur, C., Cliff, M. J., Carter, R., James, R. F., Clarke, A. R., and Hirst, T. R. (2002) J. Biol. Chem. 277, 16697-16704

7. Hahn, P. Y., Evans, S. E., Kottom, T. J., Standing, J. E., Pagano, R. E., and Limper, A. H. (2003) J. Biol. Chem. 278, 2043-2050

8. Karlsson, K. A. (1989) Annu. Rev. Biochem. 58, 309-350

9. Manes, S., del Real, G., and Martinez, A. C. (2003) Nat. Rev. Immunol. 3, 557-568

10. Zimmerman, J. W., Lindermuth, J., Fish, P. A., Palace, G. P., Stevenson, T. T., and DeMong, D. E. (1998) J. Biol. Chem. 273, 22014-22020 11. Hakomori, S., and Zhang, Y. (1997) Chem. Biol. 4, 97-104

12. Hakomori Si, S. I. (2002) Proc. Natl. Acad. Sci. U S A 99, 225-232

13. Kojima, N., and Hakomori, S. (1991) J. Biol. Chem. 266, 17552-17558

14. Iwabuchi, K., Yamamura, S., Prinetti, A., Handa, K., and Hakomori, S. (1998) J. Biol. Chem. 273, 9130-9138

15. Prinetti, A., Iwabuchi, K., and Hakomori, S. (1999) J. Biol. Chem. 274, 20916-20924

16. Hakomori, S. (2000) Glycoconj. J. 17, 627-647

17. Kojima, N., and Hakomori, S. (1991) J. Biol. Chem. 266, 17552-17558

18. Matsuura, K., Oda, R., Kitakouji, H., Kiso, M., Kitajima, K., and Kobayashi, K. (2004) Biomacromolecules 5, 937-941

19. Bucior, I., Scheuring, S., Engel, A., and Burger, M. M. (2004) J. Cell Biol. 165, 529-537

20. Kojima, N., and Hakomori, S. (1989) J. Biol. Chem. 264, 20159-20162

21. Haseley, S. R., Vermeer, H. J., Kamerling, J. P., and Vliegenthart, J. F. (2001) Proc. Natl. Acad. Sci. USA 98, 9419-9424

22. Hakomori, S., Handa, K., Iwabuchi, K., Yamamura, S., and Prinetti, A. (1998) Glycobiology 8, xi-xix

23. Brown, D. A., and London, E. (1997) Biochem. Biophys. Res. Commun. 240, 1-7

24. Brown, D. A., and London, E. (1998) Annu. Rev. Cell Dev. Biol. 14, 111-136

25. Iwabuchi, K., Handa, K., and Hakomori, S. (1998) J. Biol. Chem. 273, 33766-33773

26. Greenberg, S., and Grinstein, S. (2002) Curr. Opin. Immunol. 14, 136-145

27. Arai, T., Bhunia, A. K., Chatterjee, S., and Bulkley, G. B. (1998) Circ. Res. 82, 540-547

28. Parolini, I., Sargiacomo, M., Lisanti, M. P., and Peschle, C. (1996) Blood 87, 3783-3794

29. Gaudry, M., Gilbert, C., Barabe, F., Poubelle, P. E., and Naccache, P. H. (1995) Blood 86, 3567-3574

30. Lal, A. S., Clifton, A. D., Rouse, J., Segal, A. W., and Cohen, P. (1999) Biochem. Biophys. Res. Commun. 259, 465-470

31. Corey, S., Eguinoa, A., Puyana-Theall, K., Bolen, J. B., Cantley, L., Mollinedo, F., Jackson, T. R., Hawkins, P. T., and Stephens, L. R. (1993) Embo J 12, 2681-2690

32. Yu, W., Cassara, J., and Weller, P. F. (2000) Blood 95, 1078-1085

33. Rane, M. J., Carrithers, S. L., Arthur, J. M., Klein, J. B., and McLeish, K. R. (1997) J Immunol 159, 5070-5078

34. Vlahos, C. J., Matter, W. F., Brown, R. F., Traynor-Kaplan, A. E., Heyworth, P. G., Prossnitz, E. R., Ye, R. D., Marder, P., Schelm, J. A., Rothfuss, K. J., and et al. (1995) J. Immunol. 154, 2413-2422

35. Resh, M. D. (1994) Cell 76, 411-413

36. Rietveld, A., and Simons, K. (1998) Biochim. Biophys. Acta. 1376, 467-479

37. Harder, T., Scheiffele, P., Verkade, P., and Simons, K. (1998) J. Cell Biol. 141, 929-942

38. Iwabuchi, K., Zhang, Y., Handa, K., Withers, D. A., Sinay, P., and Hakomori, S. (2000) J. Biol. Chem. 275, 15174-15181

39. Sakiyama, H., Takahashi, T., Hirabayashi, Y., and Taniguchi, M. (1987) Cell Struct. Funct. 12, 93-105

40. Goyert, S. M. (1996) in CDw17 workshop panel report. Leukocyte Typing VI -White cell differentiation antigen- (Kishimoto T., G. S., Kikutani H., Mason D., Miyasaka M., Moretta L., Ohno T., Okumura K., Shaw S., Springer T.A., Sugamura K., Sugawara H., von dem Borne

A.E., and Zola H., Eds.), Garland Publishing, Inc, New York \& London

41. Grant, C. W., Mehlhorn, I. E., Florio, E., and Barber, K. R. (1987) Biochim. Biophys. Acta. 902, 169-177

42. Morrow, M. R., Singh, D., Lu, D., and Grant, C. W. (1995) Biophys. J. 68, 179-186

43. Prinetti, A., Marano, N., Prioni, S., Chigorno, V., Mauri, L., Casellato, R., Tettamanti, G., and Sonnino, S. (2000) Glycoconj. J. 17, 223-232 44. Ullrich, A., and Schlessinger, J. (1990) Cell 61, 203-212

45. Pike, L. J. (2003) J. Lipid Res. 1, 1

46. Pike, L. J. (2004) Biochem. J. 378, 281-292 
47. Kusumi, A., Koyama-Honda, I., and Suzuki, K. (2004) Traffic 5, 213-230

48. Nohara, K., Wang, F., and Spiegel, S. (1998) Breast Cancer Res. Treat 48, 149-157

49. Wang, X. Q., Sun, P., O’Gorman, M., Tai, T., and Paller, A. S. (2001) Glycobiology 11, 515-522

50. Hakomori, S. (2004) Arch. Biochem. Biophys. 426, 173-181

51. Miura, Y., Kainuma, M., Jiang, H., Velasco, H., Vogt, P. K., and Hakomori, S. (2004) Proc. Natl. Acad. Sci. U S A 101, 16204-16209

52. Wang, X., Sun, P., Al-Qamari, A., Tai, T., Kawashima, I., and Paller, A. S. (2001) J. Biol. Chem. 276, 8436-8444

Received on December 13, 2004, accepted on December 18, 2004

Profile of the Author

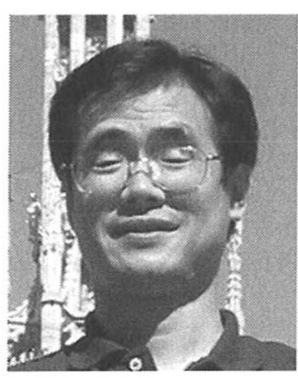

Kazuhisa Iwabuchi graduated from Tokyo Science University, School of Pharmaceutical Science (in 1984), and obtained a masters degree from Osaka University Graduate School of Pharmaceutical Science (in 1986), then obtained a Ph.D. from Juntendo University (in 1992). He started biochemical research on the molecular mechanisms of neutrophil adhesion and migration at the Department of Biochemistry, Juntendo University School of Medicine as Assistant Professor in 1986. He joined Dr. Sen-itiroh Hakomori's laboratory as a senior fellow scientist, Department of Pathobiology, Washington University School of Public Health and Community Medicine, Seattle, Washington, USA. (1997-1999). After coming back to Juntendo University as Assistant Professor, he became a Lecturer at Juntendo University School of Medicine ( in 2002).

Since 2004, he has been Associate Professor of the Laboratory of Biochemistry, Juntendo University School of Health Care and Nursing, and of the Institute for Environmental and Gender-specific Medicine, Juntendo University Graduate School of Medicine. He is also a visiting scientist at Sphingolipid Functions Laboratory, Frontier Research System, RIKEN. 